\title{
Evaluation of the efficacy of XP-endo Finisher, Easy Clean, Passive ultrasonic irrigation, and conventional irrigation in the removal of calcium hydroxide in simulated internal root resorption cavities
}

\author{
Avaliação da eficácia do XP-endo Finisher, Easy Clean, inrigação ulltrassônica passiva e irrigação \\ convencional na remoção de hidróxido de cálcio em cavidades de reabsorção internas simuladas
} Evaluación de la eficacia de XP-endo Finisher, Easy Clean, irrigación ultrasónica pasiva e irrigación convencional en la eliminación de hidróxido de calcio en cavidades de reabsorción interna simuladas

\begin{abstract}
This study aimed to evaluate the efficacy of 5 irrigation protocols in removing calcium hydroxide in simulated internal root resorption cavities. Eighteen extracted human teeth, upper anterior and uniradicular, were prepared up to size 50. The teeth were divided longitudinally, and internal root resorption cavities were made by acid demineralization using nitric acid. The same sample was submitted to the five irrigation protocols. The cavities and root canals were filled with Ultracal XS (Ultradent, South Jordan, UT, USA) and stored in an incubator at $37^{\circ} \mathrm{C}$ for one week. Afterward, the irrigation protocols were carried out: XP-endo Finisher (XPF; FKG, La Chaux-de-Fonds, Switzerland), passive ultrasonic irrigation (PUI), Easy Clean (Bassi/Easy Equipamentos Odontológicos, Belo Horizonte, Brazil) with reciprocating movement (ECR), Easy Clean with continuous rotation (ECC) and conventional irrigation with a syringe (CI). The solutions used, $2.5 \% \mathrm{NaOCl}$, and $17 \%$ EDTA, were warmed. The total volume of irrigant used for each sample was $20 \mathrm{~mL}(10 \mathrm{~mL}$ of $2.5 \% \mathrm{NaOCl}, 5 \mathrm{~mL}$ of $17 \%$ EDTA and $5 \mathrm{~mL}$ of distilled water). The amount of calcium hydroxide remaining in the internal resorption after irrigation was assessed using scores. The data were analyzed using the Pearson and Kruskal-Wallis (Dunn) tests. Significantly more calcium hydroxide was removed in the XPF group than all other sample groups $(\mathrm{P}<0.0001)$. XPF was superior to the other methods tested to remove calcium hydroxide in teeth with simulated internal resorptions.
\end{abstract}

Keywords: Dental pulp cavity; Endodontics; Root canal irrigation. 


\begin{abstract}
Resumo
Este estudo teve como objetivo avaliar a eficácia de 5 protocolos de irrigação na remoção de hidróxido de cálcio em cavidades de reabsorção internas simuladas. Dezoito dentes humanos extraídos, anteriores superiores e unirradiculares, foram preparados até o tamanho 50. Os dentes foram divididos longitudinalmente e as cavidades de reabsorção interna foram feitas por desmineralização ácida com ácido nítrico. A mesma amostra foi submetida aos cinco protocolos de irrigação. As cavidades e canais radiculares foram preenchidos com Ultracal XS (Ultradent, South Jordan, UT, EUA) e armazenados em incubadora a $37^{\circ} \mathrm{C}$ por uma semana. Posteriormente, foram realizados os protocolos de irrigação: XP-endo Finisher (XPF; FKG, La Chaux-de-Fonds, Suíça), irrigação ultrassônica passiva (PUI), EasyClean (Bassi/Easy Equipamentos Odontológicos, Belo Horizonte, Brasil) com movimento reciprocante (ECR), EasyClean com rotação contínua (ECC) e irrigação convencional com seringa (IC). As soluções utilizadas, $2,5 \% \mathrm{NaOCl}$ e $17 \%$ EDTA, foram aquecidas. O volume total de irrigante utilizado para cada amostra foi de $20 \mathrm{~mL}$ (10 mL de $\mathrm{NaOCl} 2,5 \%, 5 \mathrm{~mL}$ de EDTA $17 \%$ e $5 \mathrm{~mL}$ de água destilada). A quantidade de hidróxido de cálcio remanescente na reabsorção interna após a irrigação foi avaliada por meio de escores. Os dados foram analisados pelos testes de Pearson e Kruskal-Wallis (Dunn). Significativamente mais hidróxido de cálcio foi removido no grupo XPF do que todos os outros grupos $(\mathrm{P}<0,0001)$. XPF foi superior aos outros métodos testados para remover hidróxido de cálcio em dentes com reabsorções internas simuladas.
\end{abstract}

Palavras-chave: Cavidade pulpar; Endodontia; Irrigação do canal radicular.

\title{
Resumen
}

Este estudio tuvo como objetivo evaluar la eficacia de 5 protocolos de riego en la eliminación de hidróxido de calcio en cavidades de reabsorción interna simuladas. Se prepararon dieciocho dientes humanos extraídos, anterior superior y unirradicular, hasta el tamaño 50. Los dientes se dividieron longitudinalmente y las cavidades de reabsorción interna se realizaron mediante desmineralización ácida con ácido nítrico. La misma muestra se sometió a los cinco protocolos de riego. Las cavidades y conductos radiculares se rellenaron con Ultracal XS (Ultradent, South Jordan, UT, EE. UU.) $\mathrm{Y}$ se almacenaron en una incubadora a $37^{\circ} \mathrm{C}$ durante una semana. Posteriormente, se llevaron a cabo los protocolos de riego: XP-endo Finisher (XPF; FKG, La Chaux-de-Fonds, Suiza), riego ultrasónico pasivo (PUI), Easy Clean (Easy Equipamentos Odontológicos, Belo Horizonte, Brasil) con movimiento alternativo (ECR), Easy Clean con rotación continua (ECC) e irrigación convencional con jeringa (CI). Se calentaron las soluciones utilizadas, $\mathrm{NaOCl}$ al $2,5 \%$ y EDTA al $17 \%$. El volumen total de irrigante utilizado para cada muestra fue de $20 \mathrm{~mL}(10 \mathrm{~mL}$ de $\mathrm{NaOCl}$ al $2.5 \%, 5$ mL de EDTA al $17 \%$ y $5 \mathrm{~mL}$ de água destilada). La cantidad de hidróxido de calcio que queda en la reabsorción interna después de la irrigación se evaluó mediante puntuaciones. Los datos se analizaron mediante las pruebas de Pearson y Kruskal-Wallis (Dunn). Se eliminó significativamente más hidróxidos de calcio en el grupo XPF que en todos los demás grupos de muestras ( $\mathrm{P}<0,0001)$. XPF fue superior a los otros métodos probados para eliminar el hidróxido de calcio en dientes con reabsorciones internas simuladas.

Palabras clave: Cavidad pulpar dental; Endodoncia; Irrigación del conducto radicular.

\section{Introduction}

According to its location, root resorption results from the clastic cells activity on mineralized tissues and is classified as internal or external (Patel et al. 2010). Internal root resorption begins within the root canal and requires vital pulp tissue, usually caused by some trauma and tends to be asymptomatic (Majorana et al. 2003). When detected early, treatment is often successful, and the prognosis is favorable (Gabor et al. 2012). Endodontic treatment is the treatment of choice for this pathological condition (Haapasalo 2006), but the resorption cavity's irregular borders pose technical difficulties in preparing the canal and its obturation (Haapasalo 2006).

Calcium hydroxide $\left(\mathrm{Ca}(\mathrm{OH})_{2}\right)$ is used as an intracanal medication to treat internal root resorption when it is impossible to treat it in only one session (Mohammadi \& Dummer, 2011). The removal of $\mathrm{Ca}(\mathrm{OH})_{2}$ before the obturation is recommended because remnants retained in these extensions may interfere with the penetration and adhesion of sealers in dentinal tubules (Calt \& Serper, 1999) and also with their physical properties (Margelos et al. 1997). A frequently described method for removing $\mathrm{Ca}(\mathrm{OH})_{2}$ from the root canal is root canal instrumentation in combination with irrigation with $\mathrm{NaOCl}$ and EDTA (Salgado et al. 2009, Keskin et al. 2017, Dioguardi et al. 2018). However, previous studies have demonstrated the ineffectiveness of conventional irrigation techniques in removing $\mathrm{Ca}(\mathrm{OH})_{2}$ from root canal irregularities (Keskin et al. 2017, Topcuoglu et al. 2015, Wigler et al. 2017).

Alternative techniques of irrigating agitation are necessary for effective root canal cleaning (Fernandes et al. 2020). 
Among the available techniques we chose three for this study: 1- Passive ultrasonic irrigation (PUI), a technique that consists of ultrasonic tips activation inside the canal, promotes energy release by cavitation and acoustic microstreaming of the liquid (van der Sluis et al. 2007, Jiang et al. 2011, Macedo et al. 2014). 2- An instrument made of a plastic called EasyClean (25.04) (Bassi/Easy Equipamentos Odontológicos, Brazil) was developed for promoting the cleaning of the apical third by rotating or reciprocating agitation (Kato, et al 2016, Duque et al. 2017). 3- A nickel-titanium file (XP-endo Finisher; FKG, La Chaux-deFonds, Switzerland) with a size \#25, non-tapered instrument, designed to reach difficult-to-access areas (alternating martensite and austenite phases according to temperature) adapts to the root canal in a three-dimensional way (Keskin C et al. 2017).

Based on evidence that better results can be obtained in removing intracanal $\mathrm{Ca}(\mathrm{OH})_{2}$ using agitation protocols for irrigants (Keskin et al. 2017, Topcuoglu et al. 2015, Wigler et al. 2017) it is crucial to evaluate these protocols in teeth with simulated internal resorption. We considered the null hypothesis that different irrigation methods are equally effective in removing $\mathrm{Ca}(\mathrm{OH})_{2}$.

\section{Methodology}

The local ethics committee approved this study (No. 2.485.437). Eighteen extracted human teeth, upper anterior with single straight root, showing complete root formation, were selected. Teeth with internal or external resorption, cracks or fractures, previous endodontic treatment, curvatures more outstanding than $15^{\circ}$, and calcified canals were excluded. A radiographic examination confirmed the presence of a single root canal. The specimens were stored in $0.1 \%$ thymol (Lenzafarm, Belo Horizonte, Brazil). The crowns were removed to standardize the root length to $20 \mathrm{~mm}$. After preparing the access cavities using spherical diamond tips, the working lengths (WL) were defined by introducing a \#15 K-file (MailleferDentsply, Ballaigues, Switzerland) until its tip was visible in the foramen and by subtracting $1 \mathrm{~mm}$ from that measurement. The canals were instrumented by using Reciproc system (VDW, Munich, Germany) up to size R50 (50.05) under irrigation with $5 \mathrm{~mL}$ of $2.5 \% \mathrm{NaOCl}$ (Lenzafarm, Rio De Janeiro, Brazil) delivered with a 30-gauge needle (NaviTip; Ultradent, South Jordan, UT, USA) positioned $1 \mathrm{~mm}$ short of WL. After completing mechanical preparation, the canals were irrigated with 5 $\mathrm{mL}$ of distilled water and dried with paper points.

The specimens were embedded in silicone impression material (Zetaplus; Zhermack, Rovigo, Italy) placed in $1.5 \mathrm{~mL}$ Eppendorf tubes. After the silicone set, the specimens were removed, and longitudinal grooves were prepared along with the roots on buccal and lingual surfaces. The teeth were then cleaved along the long axis.

\section{Preparation of internal root resorption cavities}

A cylindrical chamber ( $2 \mathrm{~mm}$ in diameter and $2 \mathrm{~mm}$ in height) was made in the root middle third with compound resin to limit the substances' application, and the dentin was covered by the application of an adhesive system and polymerization. A demineralization protocol induced internal resorption with 5\% nitric acid and 8\% sodium hypochlorite. Samples were kept at $1^{\circ} \mathrm{C}\left( \pm 3^{\circ} \mathrm{C}\right)$ during the internal resorption induction period. At the end of 3 cycles, the chamber was detached, and residual substances were removed with a $24 \mathrm{~h}$ wash in running water (da Silveira et al. 2014).

Before $\mathrm{Ca}(\mathrm{OH})_{2}$ (Ultracal XS, Ultradent) insertion into the teeth, the roots were subjected to ultrasonic baths with $17 \%$ EDTA (Lenzafarm), running water, $2.5 \% \mathrm{NaOCl}$ and running water again, all for one minute each, and dried with paper points. For insertion the $\mathrm{Ca}(\mathrm{OH})_{2}$, we used a 29-gauge NaviTip needle (Ultradent). The root halves were reassembled in their molds, and the access cavities were sealed with temporary fillings (Villevie, Joinville, Brazil). The specimens were then stored at $37^{\circ} \mathrm{C}$ and $100 \%$ humidity for one week in an incubator. The temporary fillings were then removed. A \#50 K-file (MailleferDentsply, Ballaigues, Switzerland) was introduced into the WL canal to loosen the paste and create a space for irrigation 
needle. Five teeth were used as a negative control and were not filled with $\mathrm{Ca}(\mathrm{OH})_{2}$. Five teeth were used as a positive control to ensure that there was no medication loss during transport and handling, and they were filled with $\mathrm{Ca}(\mathrm{OH})_{2}$, but no removal procedure was performed. The same sample was subjected to the five irrigation protocols, and before being reused, the teeth were subjected to the abovementioned ultrasonic baths.

\section{EasyClean reciprocating $(\mathrm{ECR})$}

The sample was irrigated with $5 \mathrm{~mL}$ of $2.5 \% \mathrm{NaOCl}, 5 \mathrm{~mL}$ of $17 \%$ EDTA and again $5 \mathrm{~mL}$ of $2.5 \% \mathrm{NaOCl}$ using a 30 gauge needle and syringe (Ultradent) and agitated with EasyClean using the VDW Silver motor (VDW, Munich, Germany) in the Reciproc All mode. The instrument was operated at $1 \mathrm{~mm}$ short of WL for $1 \mathrm{~min}$ ( 3 cycles of $20 \mathrm{~s})$ with each solution.

\section{EasyClean continuous rotation (ECC)}

The same technique described in the previous group was used, but EasyClean was operated at low speed (Dabi Atlante, Ribeirão Preto, Brazil), at about 20,000 rpm at $1 \mathrm{~mm}$ short of WL.

\section{Passive ultrasonic irrigation (PUI)}

Irrigation was performed similarly as in the previous groups but was passively agitated using a piezoelectric ultrasonic unit (Gnatus, Ribeirão Preto, Brazil) with an Irrisonic tip (Helse, Santa Rosa do Viterbo, Brazil) positioned $1 \mathrm{~mm}$ short of WL without touching the walls. The apparatus was used at $20 \%$ power by performing three cycles of $20 \mathrm{~s}(1.7 \mathrm{~mL}$ each cycle) with $5 \mathrm{~mL}$ of $2.5 \% \mathrm{NaOCl}$, followed by another three cycles of $20 \mathrm{~s}$ with $5 \mathrm{~mL}$ of $17 \%$ EDTA, ending with three cycles of $20 \mathrm{~s}$ with $5 \mathrm{~mL}$ of $2.5 \% \mathrm{NaOCl}$.

\section{XP-endo Finisher (XPF)}

XP-endo Finisher (FKG, La Chaux de Fonds, Switzerland) was used in an electric endodontic motor (VDW Silver) and cooled down to be removed from the plastic tube. Root canals were irrigated with $5 \mathrm{~mL}$ of $2.5 \% \mathrm{NaOCl}$ using a 30 -gauge needle and syringe. The XPF file was inserted into the root canal and operated at a speed of $800 \mathrm{rpm}$ and torque of $1 \mathrm{~N} / \mathrm{cm}$ for 3 cycles of 20 s with vertical movements $1 \mathrm{~mm}$ short of WL. Next, the same procedure was then performed using $5 \mathrm{~mL}$ of $17 \%$ EDTA, and another irrigation with $5 \mathrm{~mL}$ of $2.5 \% \mathrm{NaOCl}$ with agitation was performed for three cycles of $20 \mathrm{~s}$. The solutions were renewed every 20 s cycle and warmed to $38^{\circ} \mathrm{C}$ to allow the XPF to assume a hook shape in its last $10 \mathrm{~mm}$.

\section{Conventional irrigation $(\mathbf{C I})$}

Irrigation was performed similarly as in the previous groups using a 30-gauge needle (Ultradent) positioned $1 \mathrm{~mm}$ short of WL. No irrigant agitation was performed.

At the end of the protocols, each sample was irrigated with $5 \mathrm{~mL}$ of distilled water. The total irrigant volume for each sample was $20 \mathrm{~mL}(5 \mathrm{~mL}$ of $2.5 \% \mathrm{NaOCl}+5 \mathrm{~mL}$ of $17 \%$ EDTA $+5 \mathrm{~mL}$ of $2.5 \% \mathrm{NaOCl}+5 \mathrm{~mL}$ of distilled water). The solutions were warmed to $38^{\circ} \mathrm{C}$ in all groups. An endodontic specialist performed all the procedures.

The root halves were separated, and digital images of each half's internal root resorptions were obtained using a stereomicroscope at 20x magnification. The sequence of all images was randomized, and two examiners blinded to group assignment evaluated each image. The amount of $\mathrm{Ca}(\mathrm{OH})_{2}$ remaining in the internal resorption cavity after irrigation was scored using the following classification described by Van der Sluis et al. 2007: 0 - cavity is empty, 1 - less than half of cavity is filled with $\mathrm{Ca}(\mathrm{OH})_{2}, 2$ - more than half of cavity is filled with $\mathrm{Ca}(\mathrm{OH})_{2}, 3$-cavity is completely filled with $\mathrm{Ca}(\mathrm{OH})_{2}$. $(\mathrm{Figure}$ 1) 
Figure 1. Representative images of scores. A) Score 0: cavity is empty. B) Score 1: less than half of cavity is filled with $\mathrm{Ca}(\mathrm{OH})_{2}$. C) Score 2: more than half of cavity is filled with $\mathrm{Ca}(\mathrm{OH})_{2}$. D) Score 3: cavity is completely filled with $\mathrm{Ca}(\mathrm{OH})_{2}$.

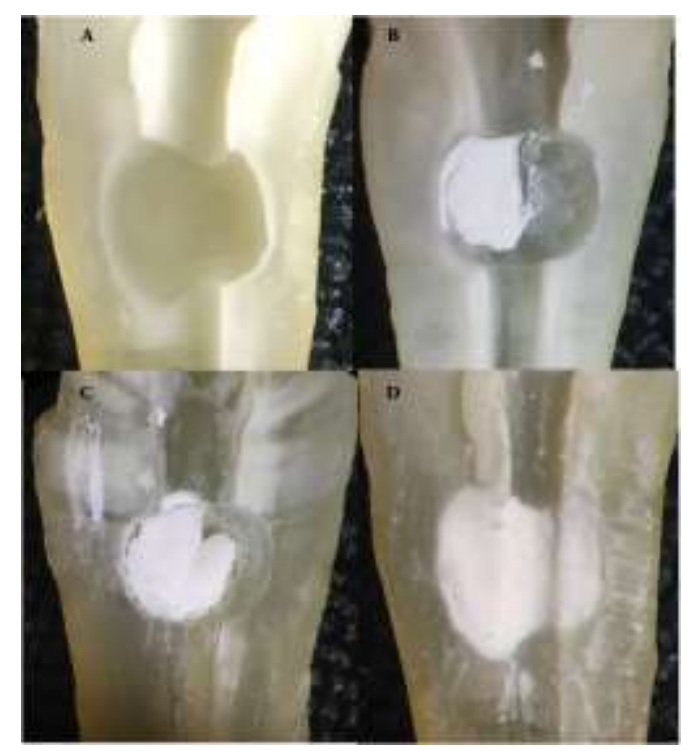

Source: Authors.

The Shapiro-Wilk revealed a non-normal distribution of data, so the Kruskal-Wallis (Dunn) test at a 5\% level of significance was used to compare the groups tested. Statistical analyses were done using the Biostat 4.0 program.

\section{Results}

The inter-examiner agreement was 0.8177 ( $\mathrm{P}<0.0001)$, as determined by the Pearson correlation test. Tables 1 and 2 detail the distribution of scores for all groups. Positive control specimens confirmed that Ultracal XS was not lost from the wells during disassembly and transport. The Kruskal-Wallis (Dunn) test showed that there was a statistically significant difference in $\mathrm{Ca}(\mathrm{OH})_{2}$ removal scores between the groups tested $(\mathrm{P}<0.0001)$. XPF removed significantly more $\mathrm{Ca}(\mathrm{OH})_{2}$ than did all other groups tested $(\mathrm{P}<0.0001)$. There was no statistically significant difference between CI and ECR $(\mathrm{P}>0.0001)$. 
Table 1. Distribution and percentage of scores of groups tested.

\begin{tabular}{|c|c|c|c|c|c|}
\hline \multirow[b]{2}{*}{ Groups } & \multicolumn{5}{|c|}{ Score for $\mathrm{Ca}(\mathrm{OH})_{2}$ removal } \\
\hline & teeth/halves & $0(\%)$ & $1(\%)$ & $2(\%)$ & $3(\%)$ \\
\hline Control - & $5 / 10$ & $10(100)$ & $0(0)$ & $0 \quad(0)$ & O \\
\hline Control + & $5 / 10$ & $0 \quad(0)$ & $0(0)$ & $0 \quad(0)$ & 10 \\
\hline ECC & $18 / 36$ & $0 \quad(0)$ & $3(8.3)$ & $19(52.7)$ & $14(38.8)$ \\
\hline ECR & $18 / 36$ & $0 \quad(0)$ & $0(0)$ & $8(22.2)$ & $28(77.7)$ \\
\hline CI & $18 / 36$ & $0 \quad(0)$ & $1(2.7)$ & $2(5.5)$ & 33 (91.6) \\
\hline PUI & $18 / 36$ & 4 (11.1) & $16(44.4)$ & $10(27.7)$ & $6(16.6)$ \\
\hline XPF & $18 / 36$ & $27(75)$ & $9(25)$ & $0(0)$ & $\mathbf{0}(\mathbf{0})$ \\
\hline
\end{tabular}

ECC - EasyClean continuous rotation, ECR - EasyClean reciprocating, CI - Conventional irrigation, PUI - Passive ultrasonic irrigation, XPF - XP Endo finisher.

Source: Authors.

Table 2. Minimum values (MN), maximum values (MX), medians (MD), interquartile deviations (ID) and statistical analysis using the Kruskal-Wallis (Dunn) test for amount of remaining $\mathrm{Ca}(\mathrm{OH})_{2}$ of the experimental groups, according to the classification of Van der Sluis et al. (2007).

\begin{tabular}{lllllll}
\hline & ECR & ECC & PUI & XP & IC & P \\
\hline $\mathrm{N}$ & 36 & 36 & 36 & 36 & 36 & \\
$\mathrm{MN}$ & 2 & 1 & 0 & 0 & 1 & \\
$\mathrm{MX}$ & 3 & 3 & 3 & 1 & 3 & $<0.0001$ \\
$\mathrm{MD}$ & 3.00 & 2.00 & 1.00 & 0.00 & 3.00 & \\
$(\mathrm{ID})$ & $(0.00)^{\mathrm{Aa}}$ & $(1.00)^{\mathrm{A}}$ & $(1.00)^{\mathrm{Ab}}$ & $(0.25)^{\mathrm{B}}$ & $(0.00)^{\mathrm{Aa}}$ &
\end{tabular}

Different upper- and lower-case letters in a row: $\mathrm{P}<0.0001$. ECC - Easy clean continuous rotation, ECR - Easy clean reciprocating, CI Conventional irrigation, PUI - Passive ultrasonic irrigation, XPF - XP Endo finisher.

Source: Autors.

\section{Discussion}

$\mathrm{Ca}(\mathrm{OH})_{2}$ can be used as an intracanal medication to treat internal root resorption because of its ability to increase $\mathrm{pH}$, control bleeding and promote residual pulp necrosis (Haapasalo et al. 2006). Previous studies have used burs to simulate internal root resorption (Keskin et al. 2017, Topcuoglu et al. 2015). This technique advantage is the standardization of the cavities, but these cavities show regular borders to compare natural resorptions, which are irregular lesions. In the present study, the root resorptions were induced by acid demineralization, and this method produces irregular cavities, very close to the clinical situation in vivo (da Silveira PF et al. 2014). The same sample was submitted to the five irrigation protocols to work 
around the fact that with cavities induced by acid demineralization, it would not be possible to control these cavities' depth. Therefore, the same cavities were analyzed in all protocols (Calt Set al. 1999, Margelos et al. 1997, Barbizam et al 2008, Ghabraei et al. 2017).

Besides the instrument's physical action, the irrigant's chemical and mechanical properties also play an essential role in the removal of $\mathrm{Ca}(\mathrm{OH})_{2}$ (Salgado et al. 2009). A previous study showed that the use of $15 \%$ EDTA or $\mathrm{NaOCl}$ alone could not remove $\mathrm{Ca}(\mathrm{OH})_{2}$ from the root canal; however, the combination of the two irrigants improved removal efficacy (Margelos et al. 1997). In the present study, similarly to previous studies, $\mathrm{NaOCl}$ and EDTA's combined use was tested (Keskin et al. 2017).

Previous studies have demonstrated the ineffectiveness of conventional irrigation techniques in removing $\mathrm{Ca}(\mathrm{OH})_{2}$ from root canal irregularities (Keskin et al. 2017, Topcuoglu et al 2015, Wigler et al. 217, Ghabraei et al.2017). Thus, in the present study, additional steps using XPF, ECC, ECR, PUI, and CI were tested to remove $\mathrm{Ca}(\mathrm{OH})_{2}$ from the resorption cavities. The null hypothesis that there is no significant difference between the groups tested was rejected.

This study's main finding was that the XPF instrument gave the best results for $\mathrm{Ca}(\mathrm{OH})_{2}$ removal in the simulated resorption cavities. ECR and CI had the worst performance without significant statistical differences between them.

The XPF instrument was developed to access irregular areas of the root canal system and is suggested by the manufacturer to remove intracanal medication. Wigler et al. 2017 suggested that irrigation longer than one minute with XPF should be tested. In the present study, we used the following in all protocols: $2.5 \% \mathrm{NaOCl}, 17 \%$ EDTA, and distilled water totaling $20 \mathrm{~mL}$ of irrigating solution, and three min of agitation. All solutions were warmed to $38^{\circ} \mathrm{C}$. Above $35^{\circ} \mathrm{C}$, the $\mathrm{XPF}$ instrument converts to the austenitic form and expands, and a solution at a lower temperature could adversely affect the results of that protocol in "in vitro" studies. Keskin et al. 2017 stirred the solutions for two min, without warming them with a $15 \mathrm{~mL}$ total volume of irrigant. As a result, only $25 \%$ of the cavities were utterly cleaned. In our study, $\mathrm{Ca}(\mathrm{OH})_{2} \mathrm{was}$ removed entirely in $75 \%$ of the cavities. Thus, XPF combined warmed $\mathrm{NaOCl}$ and EDTA solutions and agitation for three min increased the $\mathrm{Ca}(\mathrm{OH})_{2}$ removal from simulated internal root resorption cavities. Warming solutions seems to be of great value in obtaining better results in in vitro studies. The fact that XPF showed better results could also be explained by its expansion capacity, allowing this instrument to access the irregular resorption cavities spaces', favoring the displacement and removal of $\mathrm{Ca}(\mathrm{OH})_{2}$. These results agree with a recent study that also showed the XPF protocol's superiority in the removal of organic tissues from the interior of simulated internal resorption cavities (Ulusoy et al. 2018).

In the present study, PUI showed only $11.11 \%$ of cavities free of $\mathrm{Ca}(\mathrm{OH})_{2}$. These results contrast with previous studies that reported more than $40 \% \mathrm{Ca}(\mathrm{OH})_{2}$ free cavities (Keskin et al. 2017, Dioguardi M et al. 2018). This can be explained by the difference in power used in the ultrasonic unit, which was $20 \%$ in the current work and $60 \%$ in the previous one. Higher power leads to a more significant motion's range of the ultrasonic tip and greater cavitation and acoustic microstreaming (Ahmad et al. 1987), contributing to more effective removal of $\mathrm{Ca}(\mathrm{OH})_{2}$. In the PUI group, the insert's tip was kept static in the apical third of the canal. It is known that the phenomena of cavitation and acoustic microstreaming are more intense at the insert tip; if it is used with vertical movements along with the canal, allowing the tip to vibrate at the same level as resorption, the results could be better (Vivan et al. 2016).

The EasyClean instrument had not yet been tested for its ability to remove $\mathrm{Ca}(\mathrm{OH})_{2}$ in teeth with simulated internal root resorption cavities. In the present study, the ECC group gave better results when compared to the ECR and CI groups. This can be explained by the higher speed used with this instrument, resulting in a greater agitation of the liquids inside the root canal, which favors the displacement of $\mathrm{Ca}(\mathrm{OH})_{2}$. These results corroborate an earlier study that also tested EasyClean with reciprocating and continuous rotation movements to remove debris from canals and isthmuses (Duque JÁ et al. 2018). 
The current study showed that the worst results were obtained in the ECR and CI groups, agreeing with previous studies that reported CI's ineffectiveness in removing $\mathrm{Ca}(\mathrm{OH})_{2}$ (van der Sluis LW et al. 2007, Tasdemir T et al. 2011, Yucel AC et al. 2013). The poor performance of ECR can be attributed to its inability to create a cavitation effect.

\section{Conclusion}

The methods were tested in simulated resorption cavities in straight root canals. Further studies are required to evaluate these protocols' efficacy in simulated resorption cavities made in curved root canals, using the acid demineralization and with possible diffusion of $\mathrm{Ca}(\mathrm{OH})_{2}$ in the dentinal tubules. In conclusion, the XP-endo Finisher file method was superior to the other methods used to remove $\mathrm{Ca}(\mathrm{OH})_{2}$ in teeth with simulated internal resorption cavities.

\section{References}

Ahmad, M., Pitt Ford, T. J., \& Crum, L. A.(1987). Ultrasonic debridement of root canals: Acoustic streaming and its possible role. J Endod, 13:490-9.

Barbizam, J. V., Trope, M., Teixeira, E. C., et al. (2008). Effect of calcium hydroxide intracanal dressing on the bond strength of a resin-based endodontic sealer. Braz Dent J, 19:224-7.

Calt, S., \& Serper, A. (1999).Dentinal tubule penetration of root canal sealers after root canal dressing with calcium hydroxide. $J$ Endod, 25:431-3.

da Silveira, P. F., Vizzotto, M. B., Montagner, F., et al. (2014). Development of a new in vitro methodology to simulate internal root resorption. $J$ Endod,40:211-6.

Dioguardi, M., Di Gioia, G., Illuzzi, G., et al. (2018). Endodontic irrigants: Different methods to improve efficacy and related problems. Eur J Dent, $12: 459-66$.

Duque, J. A., Duarte, M. A., Canali, L. C., et al. (2017). Comparative effectiveness of new mechanical irrigant agitating devices for debris removal from the canal and isthmus of mesial roots of mandibular molars. J Endod,43:326-31.

Fernandes, K. G., Silva, B. B., Boer, N. C., et al. (2020). The Effectiveness of Three Irrigation Systems in the Enterococcus faecalis Reduction after Instrumentation with a Reciprocating Instrument. Eur J Dent, 14(4):539-543.

Gabor, C., Tam, E., Shen, Y., et al. (2012) Prevalence of internal inflammatory root resorption. J Endod, 38:24-7.

Ghabraei, S., Bolhari, B., Yaghoobnejad, F., \& Meraji, N. Effect of intra-canal calcium hydroxide remnants on the push-out bond strength of two endodontic sealers. Iran Endod J 2017;12:168-72.

Haapasalo, M., \& Endal, U. (2006). Internal inflammatory root resorption: The unknown resorption of the tooth. Endodontic topics, 14:60-79.

Jiang, L. M., Verhaagen, B., Versluis, M., et al. (2011). The influence of the ultrasonic intensity on the cleaning efficacy of passive ultrasonic irrigation. $J$ Endod, 37:688-92.

Kato, A. S., Cunha, R. S., da Silveira Bueno, C. E., et al. (2016). Investigation of the efficacy of passive ultrasonic irrigation versus irrigation with reciprocating activation: An environmental scanning electron microscopic study. $J$ Endod, 42:659-63.

Keskin, C., Sariyilmaz, E., \& Sariyilmaz, O. (2017). Efficacy of xp-endo finisher file in removing calcium hydroxide from simulated internal resorption cavity. J Endod, 43:126-30.

Macedo, R., Verhaagen, B., Rivas, D. F., et al. (2014)Cavitation measurement during sonic and ultrasonic activated irrigation. J Endod, 40:580-3.

Majorana, A., Bardellini, E., Conti. G., et al. (2003). Root resorption in dental trauma: 45 cases followed for 5 years. Dent Traumatol, $19: 262-5$.

Margelos, J., Eliades, G., Verdelis, C., et al. (1997). Interaction of calcium hydroxide with zinc oxide-eugenol type sealers: A potential clinical problem. $J$ Endod, 23:43-8

Mohammadi, Z., \& Dummer, P. M. (2011). Properties and applications of calcium hydroxide in endodontics and dental traumatology. Int Endod J, 44:697730 .

Patel, S., Ricucci, D., Durak, C., et al. (2010) Internal root resorption: A review. J Endod, 36:1107-21.

Salgado, R. J., Moura-Netto, C., Yamazaki, A. K., et al. (2009). Comparison of different irrigants on calcium hydroxide medication removal: Microscopic cleanliness evaluation. Oral Surg Oral Med Oral Pathol Oral Radiol Endod, 107:580-4.

Tasdemir, T., Celik, D., Er, K., et al. (2011). Efficacy of several techniques for the removal of calcium hydroxide medicament from root canals. Int Endod, 44:505-9. 
Research, Society and Development, v. 10, n. 3, e1510313023, 2021

(CC BY 4.0) | ISSN 2525-3409 | DOI: http://dx.doi.org/10.33448/rsd-v10i3.13023

Topcuoglu, H. S., Duzgun, S., \& Ceyhanli, K. T, (2015). Efficacy of different irrigation techniques in the removal of calcium hydroxide from a simulated internal root resortion cavity. Int Endod, 48:309-16.

Ulusoy, O. I., Savur, I. G., Alacam, T., et al. (2018). The effectiveness of various irrigation protocols on organic tissue removal from simulated internal resorption defects. Int Endod J, 51:1030-6.

van der Sluis, L. W., Versluis, M., Wu, M. K., et al. (2007). Passive ultrasonic irrigation of the root canal: A review of the literature. Int Endod J, 40:415-26.

van der Sluis, L.W., Wu, M. K., \& Wesselink, P. R. (2007). The evaluation of removal of calcium hydroxide paste from an artificial standardized groove in the apical root canal using different irrigation methodologies. Int Endod J, 40:52-7.

Vivan, R. R., Duque, J. A., Alcalde, M. P., et al. (2016). Evaluation of different passive ultrasonic irrigation protocols on the removal of dentinal debris from artificial grooves. Braz Dent J, 27:568-72.

Wigler, R., Dvir, R., Weisman, A., et al. (2017). Efficacy of xp-endo finisher files in the removal of calcium hydroxide paste from artificial standardized grooves in the apical third of oval root canals. Int Endod J, 50:700-5.

Yucel, A. C., Gurel, M., Guler, E., et al. (2013). Comparison of final irrigation techniques in removal of calcium hydroxide. Aust Endod J, 39:116-21. 